Polish Journal of Microbiology

2013, Vol. 62, No 1, 101-108

SHORT COMMUNICATION

\title{
Production and Characterization of Esterase in Lantinus tigrinus for Degradation of Polystyrene
}

\author{
LUBNA TAHIR ${ }^{1,2}$, MUHAMMAD ISHTIAQ ALI ${ }^{1}$, MUHAMMAD ZIA ${ }^{3 *}$, NAIMA ATIQ ${ }^{1}$ \\ and FARIHA HASAN ${ }^{1}$, SAFIA AHMED ${ }^{1}$ \\ ${ }^{1}$ Department of Microbiology, Quaid-i-Azam University Islamabad Pakistan 45320
2Pharmeceutical Section, ACRC, PCSIR Labs Complex Lahore Pakistan \\ ${ }^{3}$ Department of Biotechnology, Quaid-i-Azam University Islamabad Pakistan 45320
}

Received 3 February 2012, revised 28 September 2012, accepted 2 October 2012

Abstract

Polystyrene is considered stable to biological degradation. Lantinus tigrinus isolated from wood sample produced esterase in growth medium under normal conditions. However, acidic medium, $37^{\circ} \mathrm{C}$ temperature, presence of tween 80 ; and urea and yeast extract in mineral salt medium enhance the production of esterase and specific activity. Purified esterase was active at broad pH range and $45^{\circ} \mathrm{C}$. FTIR analysis confirmed that esterase produced by Lantinus tigrinus effectively degraded polystyrene film and broke macromolecules down to non-toxic molecules. This study concludes that the presence of Lantinus tigrinus at dumping sites can be exploited for waste management containing high molecular weight synthetic polymers.

Ke y words: Lantinus tigrinus, degradation, esterase, inducer, polystyrene

Polystyrene is a synthetic polymer widely used as loose fill packaging foam. The chemical makeup of polystyrene is a long chain hydrocarbon with every other carbon connected to a Phenyl group. Each of the chiral backbone carbon lies at the centre of a tetrahedron, with its four bonds pointing toward the vertices. The presence of chiral backbone carbon makes it highly stable and less susceptible for biodegradation. However, few reports demonstrate that some species of basidiomycetes, Alcaligenes, Pseudomonas and Azotobacter efficiently degrade polystyrene into low molecular weight compounds (Higashimura et al., 1983; Milstein et al., 1992; Nakamiya et al., 1997; Jang et al., 2006).

Esterases play an important role in maintaining normal physiology and metabolism, detoxifying various drugs and environmental toxicants in living systems (Huang and Ottea, 2004). The hydrolytic mechanism of most of the known esterases resembles the mechanism of lipases and serine proteases (Ollis et al., 1992). Esterases can hydrolyze substrates having regio-, enantio-, or stereo properties (Krishna et al., 2002).

The white-rot fungi genus Lentinus is well known to degrade environmental pollutants such as textile dyes (Niebisch et al., 2010); oil pollutants (Adenipekun and
Fasidi, 2005); agro-industry waste and de-colorization of synthetic dyes (Sarnthima et al., 2009); and also other pollutants (Aust and Benson, 1993; Bumpus et al., 1985). This fungus normally possesses an extracellular oxidative enzymatic system; ligninolytic enzymes, for degradation of organic pollutants (Mester and Tien, 2004). Recently, Covino et al. (2010 a, b) reported the presence of cytochrome P-450 epoxide hydrolase system in Lantinus tigrinus involved in degradation of PAHs (chrysene and bezopyrene) and polycyclic hydrocarbons. This strain also produces lignocellulosic enzymes such as cellulose, endoglucanase, laccase and ligninases that degrade aromatic compounds from lignin (Lechner and Papinutti, 2006). The present work demonstrates that production of esterase by Lantinus tigrinus efficiently degrades polystyrene and esterase production is influenced by $\mathrm{pH}$, temperature, inducer and nitrogen source supplied in the medium.

Lentinus tigrinus strain was isolated from wood sample and tested for production of hydrolytic enzymes on mineral salt (MS) medium. The MS media contained $0.25 \mathrm{~g} / \mathrm{l}$ citric acid; $0.02 \mathrm{~g} / \mathrm{L} \mathrm{CaCl}_{2} ; 5 \mathrm{~g} / \mathrm{L} \mathrm{K}_{2} \mathrm{HPO}_{4}$; $0.50 \mathrm{~g} / \mathrm{L} \mathrm{MgSO} \cdot 7 \mathrm{H}_{2} \mathrm{O} ; 5 \mathrm{~g} / \mathrm{L}\left(\mathrm{NH}_{4}\right)_{2} \mathrm{SO}_{4} ; 2 \%$ Tween 80 ; $10 \mathrm{~g} / \mathrm{L}$ yeast extract; and $15 \mathrm{~g} / \mathrm{L}$ agar. Lentinus tigrinus

* Corresponding author: M. Zia, Department of Biotechnology, Quaid-i-Azam University Islamabad Pakistan 45320; phone: +92-51-9064-4126; e-mail: ziachaudhary@gmail.com 
showed clear zone of hydrolysis on plates. Furthermore, production of esterase was carried out in PYD broth medium containing $5 \mathrm{~g} / \mathrm{L}$ peptone; $3 \mathrm{~g} / \mathrm{L}$ beef extract; $5 \mathrm{~g} / \mathrm{L}$ sodium chloride; $5 \mathrm{~g} / \mathrm{L}$ yeast extract, and $1 \mathrm{~g} / \mathrm{L}$ Dextrose. The PYD media was inoculated with $10 \%$ fungal homogenate and fermented at $37^{\circ} \mathrm{C}, 150 \mathrm{rpm}$ in shaker incubator for $96 \mathrm{hr}$. Samples were collected after every $24 \mathrm{hr}$ and esterase activity was performed in cell free extract. To access esterase activity, crude enzyme was treated with $1 \mathrm{M} \rho$-nitrophenyl acetate, following the procedure described by Maeda et al. (2005). The optical density was measured in spectrophotometer at $380 \mathrm{~nm}$. Standard curve was drawn by reacting crude enzyme with varying concentration of $\rho$-nitophenyl $(0.01-0.1 \mathrm{mg} / \mathrm{ml})$. One unit of esterase activity is defined as the amount of enzyme which releases $10 \mu \mathrm{g}$ of $p$-nitrophenol $/ \mathrm{ml}$ under the standard assay conditions.

For the morphological identification, Lantinus tigrinus was grown on malt extract media (Merck). After seven days of culture at $37^{\circ} \mathrm{C}$, morphological characters were observed. For molecular identification, total genomic DNA was extracted according to the method of Anderson et al. (1996) following amplification of ITS regions by PCR. Universal primers ITS-1 5'-TCCGTAGGTGAACCTGCGG-3' and ITS-4 5'-TCCTCCGCTTATTGATATGC-3' were used as previously described by Webb et al. (2000). Amplified products were purified and sequenced using the ABI BigDye Dideoxy Terminator Cycle sequencing kit (Applied Biosystems Inc., Warrington, United Kingdom) following forward and reverse sequences alignment using $\mathrm{ABI}$ Auto-assembler software (Applied Biosystems Inc.). The overlapping consensus sequence was compared with sequences in the NCBI database using FASTA 3 sequence homology searches.

For production of maximum esterase, PYD medium was used as described before in all experiments otherwise mentioned. For $\mathrm{pH}$ optimization, the $\mathrm{pH}$ of the media was adjusted to $3,4,5,6,7,8,9$ and 10 . For temperature condition standardization, inoculated media (pH 5) flasks were kept on orbital shaker at $30^{\circ} \mathrm{C}$, $37^{\circ} \mathrm{C}$ and $45^{\circ} \mathrm{C}$ at $150 \mathrm{rpm}$. Three different substrates as inducer (Tween 20, Tween 80 , and olive oil) at $1 \%$ each were also examined for enzyme production. Interaction of application of inducer with rage of temperature $\left(30^{\circ} \mathrm{C}, 37^{\circ} \mathrm{C}\right.$ and $\left.45^{\circ} \mathrm{C}\right)$ was also studies. For optimization of nitrogen source, Mineral medium $(0.25 \mathrm{~g} / \mathrm{L}$ Citric acid; $0.02 \mathrm{~g} / \mathrm{L} \mathrm{CaCl} ; 5 \mathrm{~g} / \mathrm{L} \mathrm{K}_{2} \mathrm{HPO}_{4} ; 0.50 \mathrm{~g} / \mathrm{L}$ $\left.\mathrm{MgSO}_{4} \cdot 7 \mathrm{H}_{2} \mathrm{O}\right)$ with different nitrogen sources was used. All the experiments were performed in triplicate and samples were collected at $24 \mathrm{hr}$ intervals. Enzyme assay was performed as mentioned before. Total protein was also analyzed in all samples following the method described by Lowry et al. (1951).
For partial purification of esterase, the culture filtrate was concentrated by $70 \%\left(\mathrm{NH}_{4}\right)_{2} \mathrm{SO}_{4}$ in $50 \mathrm{mM}$ Tris HCL buffer ( $\mathrm{pH}$ 8). Concentrated esterase was dialyzed by ultra-filtration (dialyzed by using 12000 M.W cut off dialyzing bag) and chromatographed using Sephadex G-75, eluted with $50 \mathrm{mM}$ tris $\mathrm{HCl}$ buffer, $\mathrm{pH} 8$. A volume of $3 \mathrm{ml}$ fraction was collected and assayed for enzyme activity and amount of protein. The procedure for enzyme assay as defined before was followed for the degradation of plastics except that instead of $\rho$-nitophenyl acetate $0.1 \%$ polystyrene film was incubated at $37^{\circ} \mathrm{C}$. After $72 \mathrm{hr}$ of incubation, the films were removed and thoroughly washed with distilled water. Degradation of the film surface was initially examined microscopically following FTIR spectroscopic analysis in an Analect RFX-75 spectrometer through standard protocol.

Growth of Lentinus tigrinus in mineral salt medium produced hydrolytic enzyme. The clear region in agar containing petri plates confirmed release of enzyme in the medium under normal conditions. Colonies of the strain were light colored, smooth and flat on the surface with sporous appearance. The isolate was identified by $5.8 \mathrm{~S}, 18 \mathrm{~S}, 28 \mathrm{~S}$ rRNA internal transcribed spacer (ITS) region sequencing. Sequences were compared with known sequences and deposited to NCBI with accession number EU543989. Increase in $\mathrm{pH}$ from acidic to basic decreased production and specific activity of esterase (Fig. 1). Maximum esterase production and specific activity was observed on $4^{\text {th }}$ day when cultured at acidic medium. However; at pH 7 and 8 , maximum activity was observed on $5^{\text {th }}$ day of culture. Lantinus tigrinus also prefered neutral to acidic condition for production of esterase like other esterase producing microbes (Buzzini and Martini, 2002; Kudanga et al., 2007). At $30^{\circ} \mathrm{C}$, esterase production gradually increased up to $5^{\text {th }}$ day of culture (Fig. 2). However, $37^{\circ} \mathrm{C}$ was found optimum for production of esterase. At this temperature maximum esterase production $(10 \mathrm{U} / \mathrm{ml})$ and maximum specific activity $(0.4 \mu \mathrm{g} / \mathrm{ml}$ protein $)$ was attained on $5^{\text {th }}$ day of culture. At all the temperatures, production and specific activity drastically decreased when culture was incubated for more then five days. Maximum esterase production from Aureobasidium pullulans has been reported at $35^{\circ} \mathrm{C}$ and its production decreased with increase of culturing temperature (Kudanga et al., 2007).

Tween 80 had a positive role in production of esterase (Fig. 3). In all the cases esterase production and specific activity was maximum at $37^{\circ} \mathrm{C}$ as compared with 30 and $45^{\circ} \mathrm{C}$. Tween 20 was also found better for production of esterase at 30 and $37^{\circ} \mathrm{C}$. However, in the presence of tween 80 specific esterase activity was higher. The results also describe that Lantinus tigrinus does not prefer the presence of fatty acids 

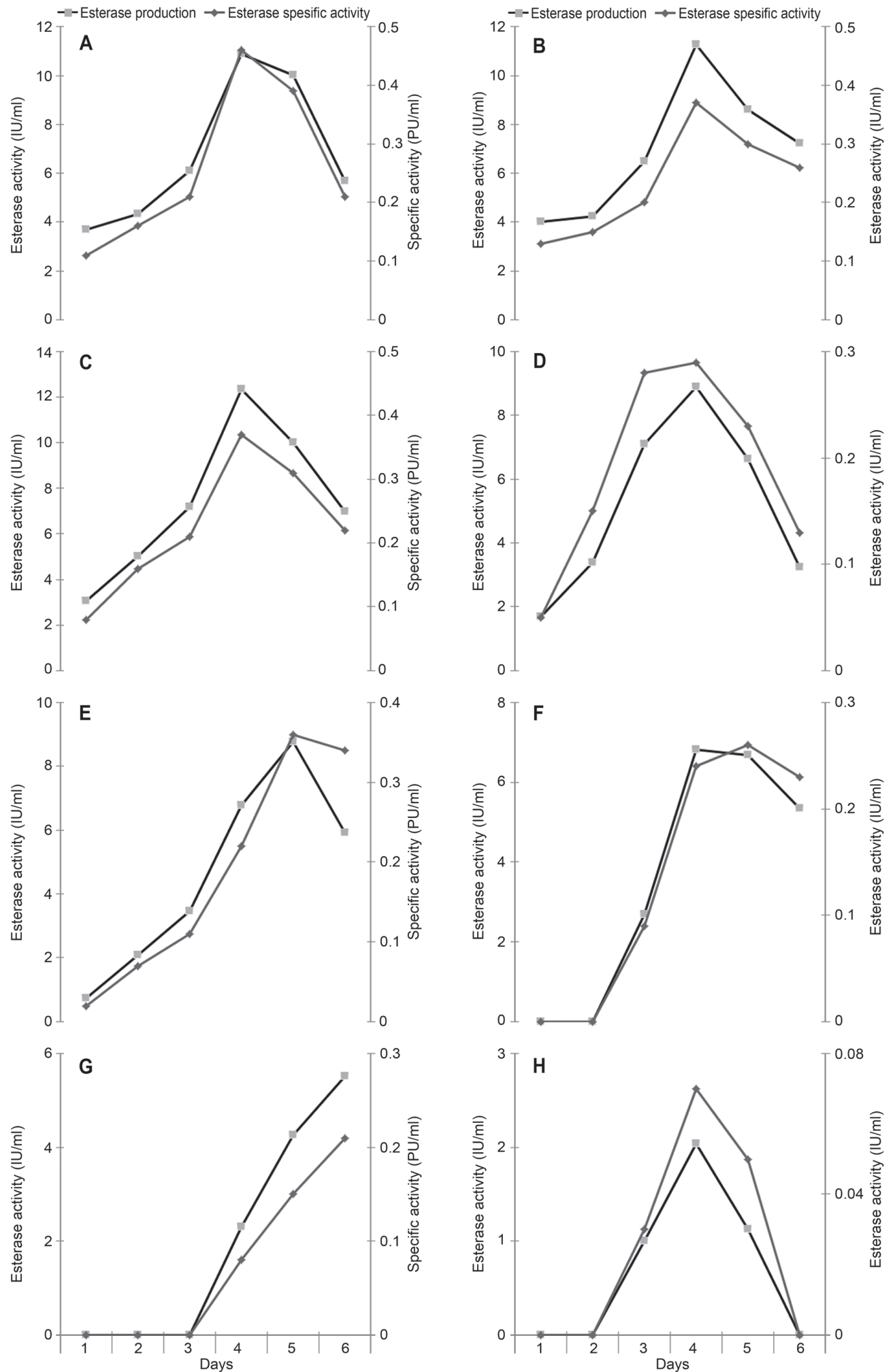

Fig. 1. Effect of different $\mathrm{pH}$ inducing esterase production by Lantinus tigrinus.

(A) $\mathrm{pH} 3.0$; (B) $\mathrm{pH} 4.0$; (C) $\mathrm{pH}$ 5.0; (D) $\mathrm{pH}$ 6.0; (E) $\mathrm{pH}$ 7.0; (F) $\mathrm{pH} 8.0$; (G) $\mathrm{pH}$ 9.0; (H) $\mathrm{pH}$ 10.0, enzyme activity is expressed in $\mathrm{U} / \mathrm{ml}$ and specific activity in $\mu \mathrm{g} / \mathrm{ml}$ protein. 

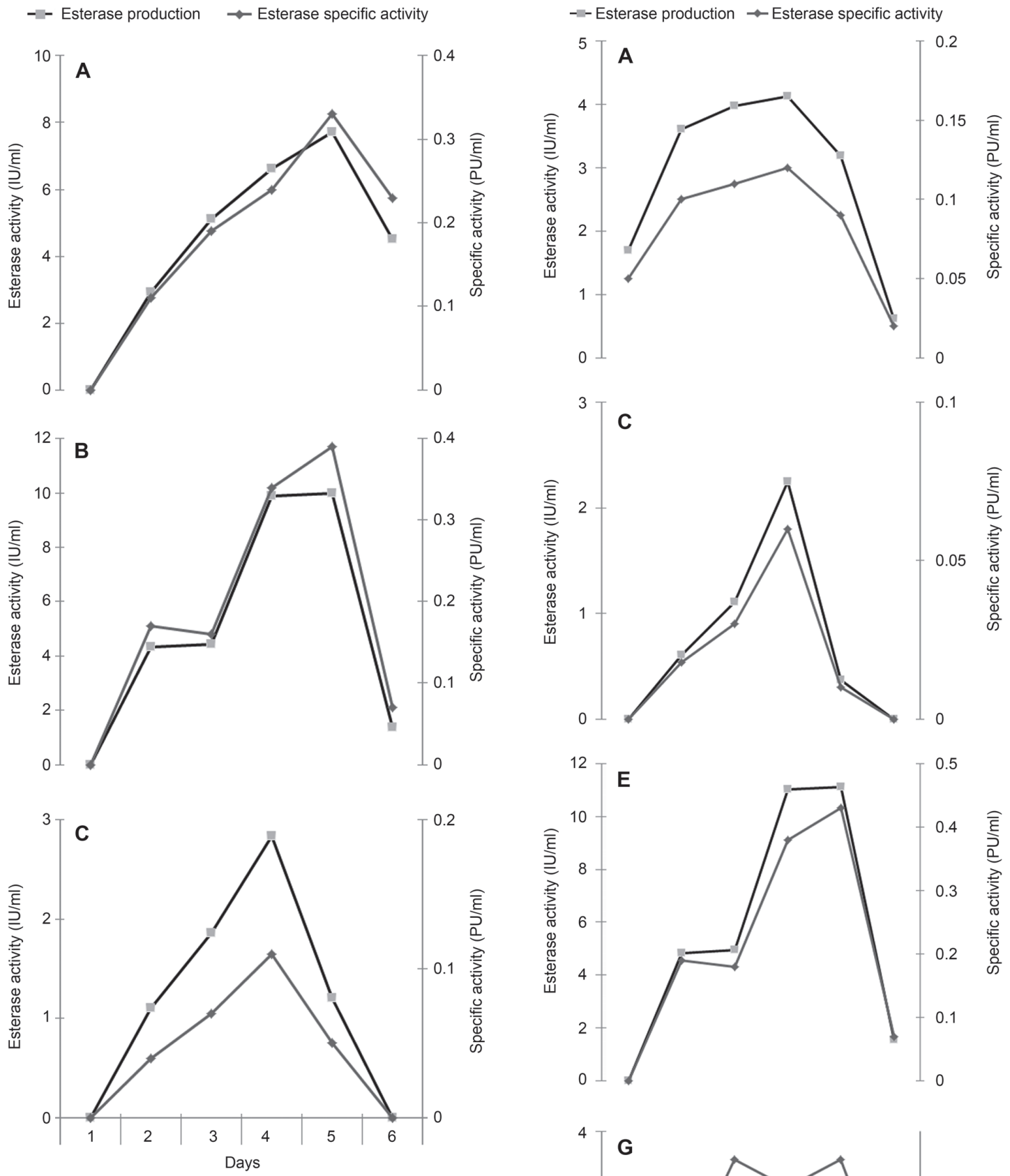

Fig. 2. Effect of different temperature inducing esterase production by Lantinus tigrinus.

(A) $30^{\circ} \mathrm{C}$; (B) $37^{\circ} \mathrm{C}$; (C) $45^{\circ} \mathrm{C}$, enzyme activity is expressed in $\mathrm{U} / \mathrm{ml}$ and specific activity in $\mu \mathrm{g} / \mathrm{ml}$ protein.

(olive oil) for production of esterase. The presence of surfactants increases cell membrane permeability, increasing the adsorption of nutrients and release of enzyme (Okagbue etal., 2001), substrate mobility (Marcozzi et al., 1998); and enhance better dispersion of the lipodal substrate which facilitates better utiliza-

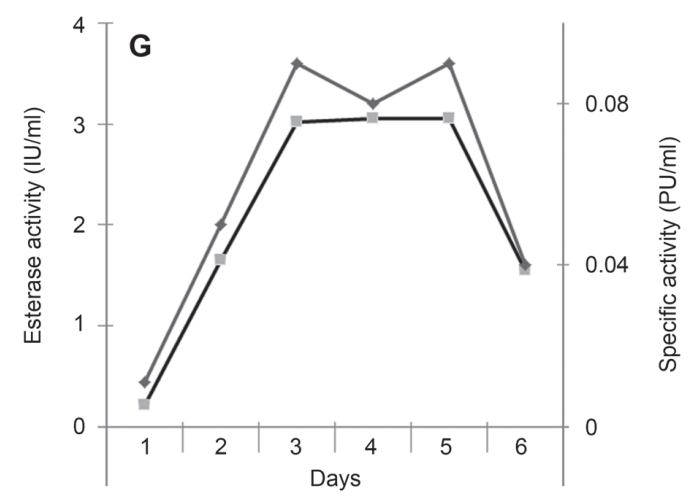

Fig. 3. 

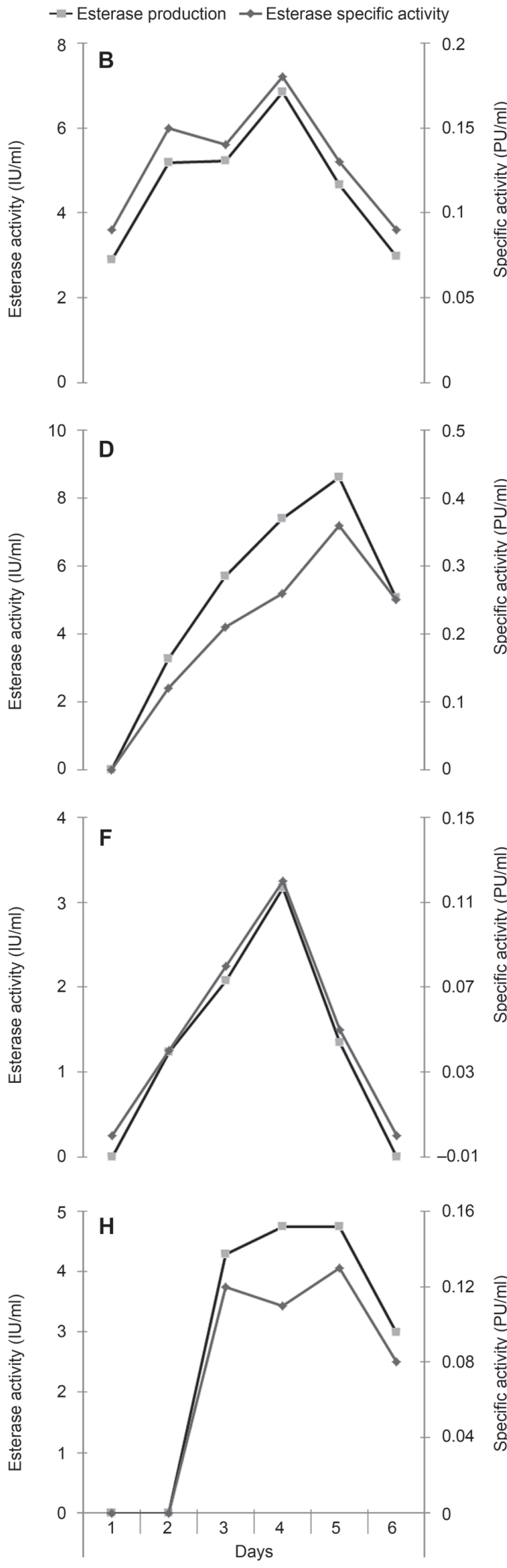

Fig. 3.

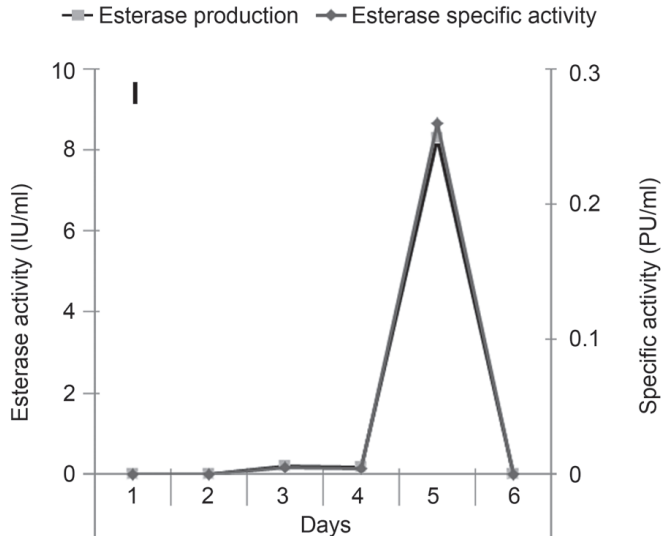

Fig. 3. Effect of different inducers inducing esterase production by Lantinus tigrinus.

(A) Tween 20 at $30^{\circ} \mathrm{C}$; (B) Tween 20 at $37^{\circ} \mathrm{C}$; (C) Tween 20 at $45^{\circ} \mathrm{C}$; (D) Tween 80 at $30^{\circ} \mathrm{C}$; (E) Tween 80 at $37^{\circ} \mathrm{C}$; (F) Tween 80 at $45^{\circ} \mathrm{C}$; (G) olive oil at $30^{\circ} \mathrm{C}$; $(\mathrm{H})$ olive oil at $37^{\circ} \mathrm{C}$; (I) olive oil at $45^{\circ} \mathrm{C}$, enzyme activity is expressed in $\mathrm{U} / \mathrm{ml}$ and specific activity in $\mu \mathrm{g} / \mathrm{ml}$ protein.

tion by the enzyme (Arthur et al., 1984). Kudanga et al. (2007) and Okagbue et al. (2001) also reported positive influence of Tween 80 for production of esterase and $\alpha$-glucosidase, respectively. The maximum esterase production $(38.62 \mathrm{U} / \mathrm{ml})$ and specific activity $(0.85 \mu \mathrm{g} / \mathrm{ml}$ protein) was achieved when cultured in the presence of urea and yeast extract (Fig. 4). Replacing the urea with ammonium sulfate decreased both production and specific activity of esterase. Other nitrogen sources did not positively influence the production of esterase. It can be stated that maximum esterase production through Lantinus tigrinus can be achieved by providing organic nitrogen sources. However, the production of enzyme in the presence of different nitrogen source also depends upon fungal strain (Kudanga et al., 2007).

Lentinus tigrinus purified esterase was optimally active at $45^{\circ} \mathrm{C}$ and $\mathrm{pH} 9$. At 25,30 and $35^{\circ} \mathrm{C}$, minute esterase activity $(<1.0 \mu \mathrm{g} / \mathrm{ml}$ protein $)$ was observed. The esterase activity reached at maximum $(4.1 \mu \mathrm{g} / \mathrm{ml}$ protein) at $45^{\circ} \mathrm{C}$ and gradually decreased when temperature was increased up to 50 and $55^{\circ} \mathrm{C}$. Blum et al. reported optima temperature $30^{\circ} \mathrm{C}$ for production of maximum acetyl xylan esterase from rumen fungus Orpinomyces sp. strain PC-2 (Blum etal., 1999). At acidic $\mathrm{pH}(4,5)$ the activity was $<0.4 \mu \mathrm{g} / \mathrm{ml}$ protein and it increased up to maximum $(4.8 \mu \mathrm{g} / \mathrm{ml}$ protein $)$ at $\mathrm{pH}$ 9. Loss of enzymatic activities at different $\mathrm{pH}$ and temperature have been reported and found that varying the assay conditions the enzyme activity may be sudden lost or minute activity may be observed (Topakas et al., 2007). The half life of the enzyme also varies by varying the temperature and $\mathrm{pH}$ condition either during production or during assay (Ewis et al., 2004). However, many scientists reported that esterases 

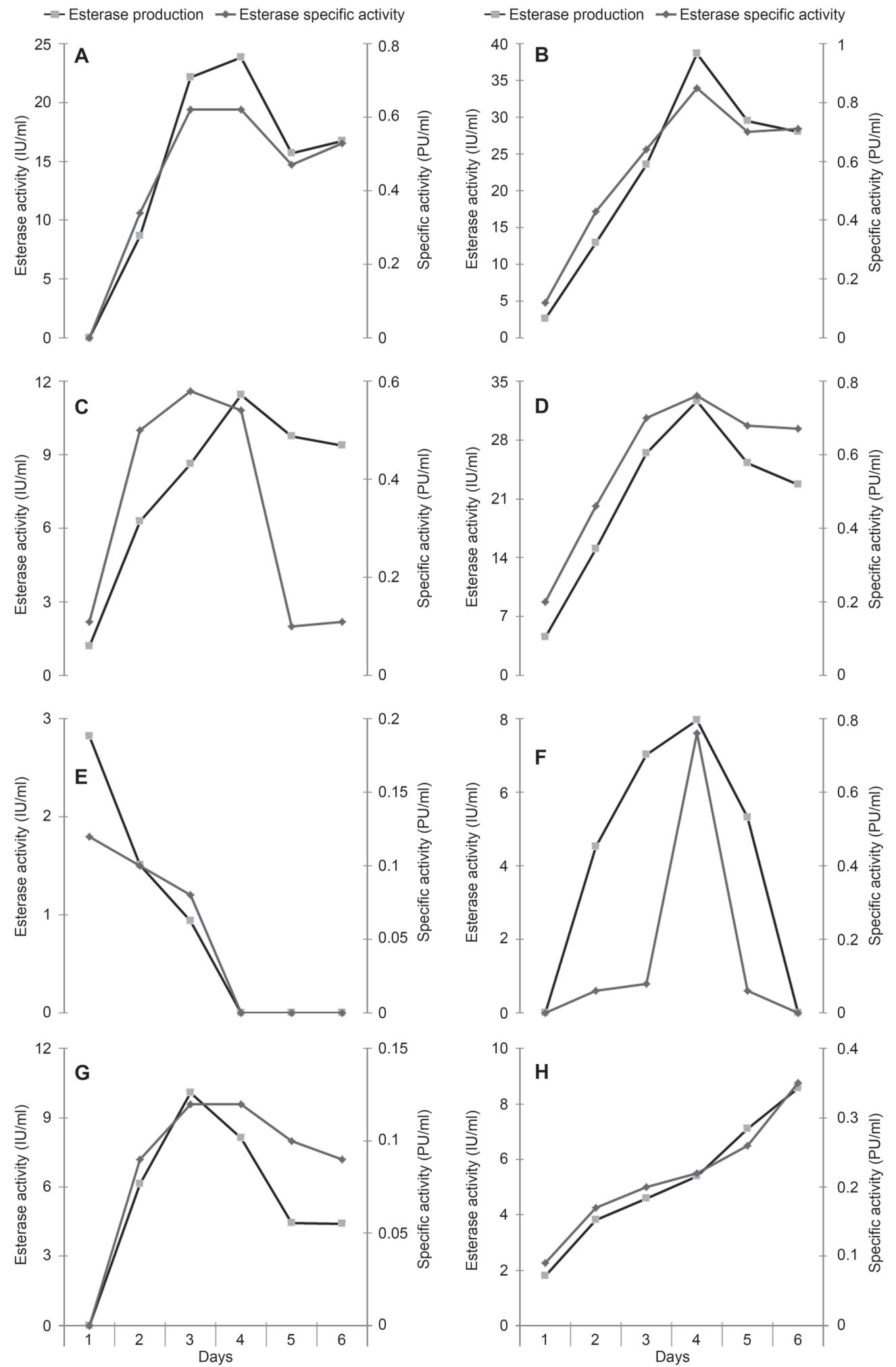

Fig. 4. Effect of different nitrogen source inducing esterase production by Lantinus tigrinus.

(A) yeast extract; (B) urea and yeast extract; (C) meat extract; (D) yeast extract and $\left(\mathrm{NH}_{4}\right)_{2} \mathrm{SO}_{4}$; (E) peptone; $(\mathrm{F}) \mathrm{KNO}_{3}$; $(\mathrm{G})\left(\mathrm{NH}_{4}\right)_{2} \mathrm{SO}_{4}$; $(\mathrm{H})$ yeast extract and $\mathrm{KNO}_{3}$, enzyme activity is expressed in $\mathrm{U} / \mathrm{ml}$ and specific activity in $\mu \mathrm{g} / \mathrm{ml}$ protein. 

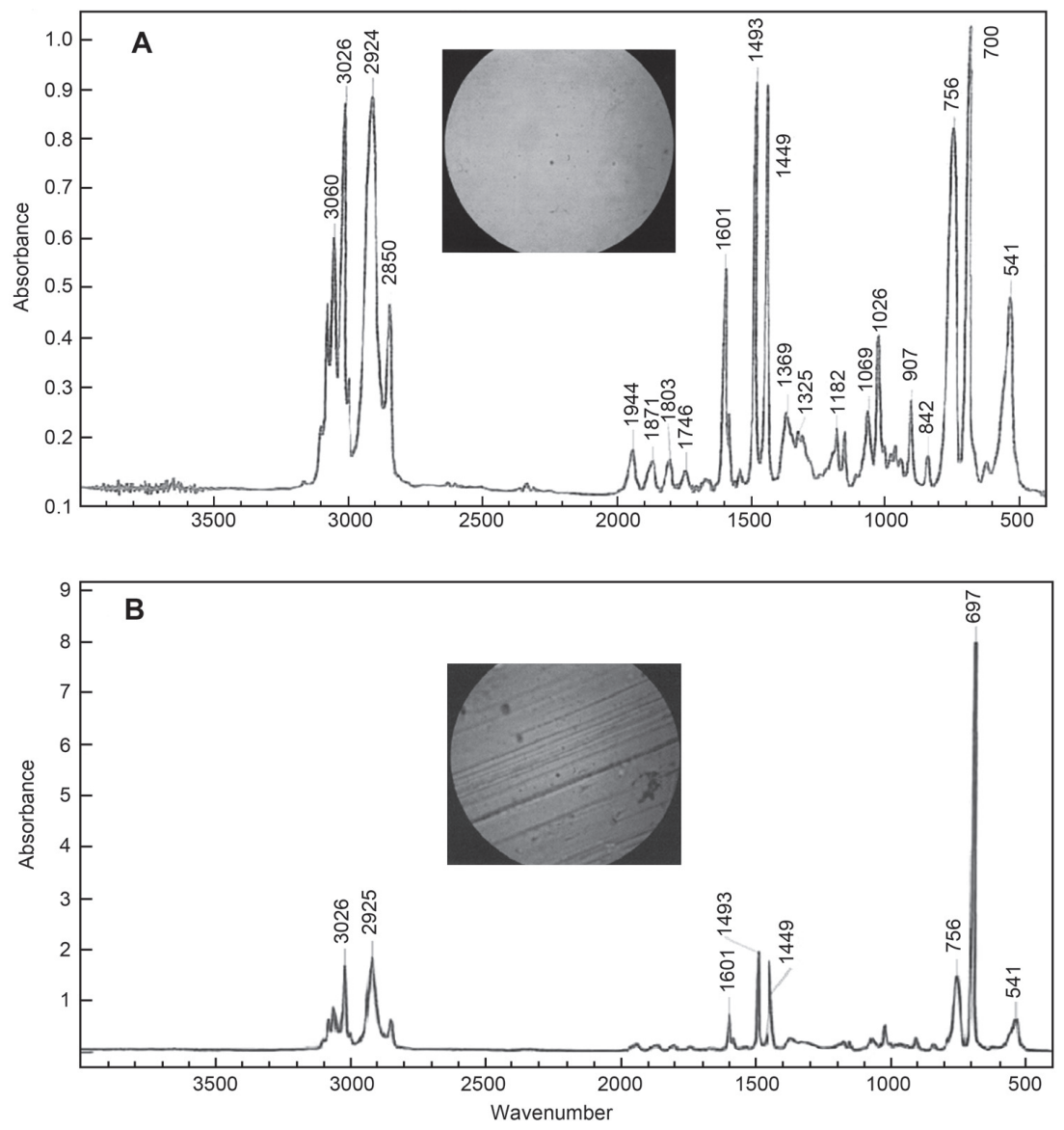

Fig. 5. FTIR analysis of polystyrene film.

(A) before treatment; (B) after treatment of esterase isolated from Lantinus tigrinus.

produced by different bacterial and fungal isolates have optimum temperature $37^{\circ} \mathrm{C}$ and basic $\mathrm{pH}$ conditions (Suzuki et al., 2004). The $\mathrm{pH}$ of the medium in which the enzyme is exposed also affects the ionization state of its amino acids which dictate the primary and secondary structure of the enzyme, thus controlling its activity. The influence of $\mathrm{pH}$ of the cultivation medium may be directly related with the stability of enzymes (Ueda et al., 1982). The polystyrene film treated with purified esterase confirmed degradation of polystyrene surface (Fig. 5). FTIR spectroscopy analysis (Fig. 5A) revealed that aromatic peaks $(1449,1493$ and $1601 \mathrm{~cm}-1)$, alkane (1026-1369 cm-1) and C-H stretch (2850-3060 cm-1) are reduced in Fig. 5(B). This shows that esterase breaks down the bonds between small units of styrene and also degrades alkanes and aromatic rings. Generally, polystyrene is considered a stable macromolecule (Zheng et al., 2005); however, long but simple chemical structure and small molecular weight polymer made it easy to be degraded by enzymatic hydrolysis. Many studies reveal that polystyrene and other stable polymers can be degraded by different enzymes (Takamoto et al., 2001; Chattopadhyay and Madras, 2003).

This study concludes that Lantinus tigrinus releases esterase enzyme in the culture medium. Production and release of esterase was influenced by temperature, $\mathrm{pH}$, nitrogen source and inducer. The enzyme was active at $45^{\circ} \mathrm{C}$ and basic medium was optimum for its activity. FTIR analysis confirms degradation of polystyrene by reduction in peak wavelength. The results presented in this study can be further exploited for environmental waste management especially when containing synthetic polymers such as polystyrene.

\section{Literature}

Adenipekun C.O. and I.O. Fasidi. 2005. Bioremediation of oilpolluted soil by Lentinus subnudus, A Nigerian white-rot fungus. African J. Biotechnol. 4: 796-798

Anderson M.J., K. Gull and D.W. Denning. 1996. Molecular typing by random amplification of polymorphic DNA and m13 southern 
hybridization of related paired isolates of Aspergillus fumigatus. J. Clin. Microbiol. 34: 87-93

Arthur G., W.T. Stanley and C.C. Patrick. 1984. The effects of detergents on CDP-choline: 1,2-diacylglycerol phosphocholine transferase from hamster heart. Canadian J. Biochem. Cell. Biol. 62 : 1059-1063

Aust S.D. and J.T. Benson. 1993. The fungus among us - use of white-rot fungi to biodegrade environmental-pollutants. Environ. Health Perspec. 101: 232-233

Blum D.L., L. Xin-Liang, C. Huizhong and G.L. Lars. 1999. Characterization of an acetyl xylan esterase from the anaerobic fungus Orpinomyces sp. strain PC-2. App. Environ. Microbiol. 9: 3990-3995 Bumpus J.A., M. Tien, D. Wright and S.D. Aust. 1985. Oxidation of persistent environmental-pollutants by a white rot fungus. Science 228: 1434-1436

Buzzini P. and A. Martini. 2002. Extracellular enzymatic activity profiles in yeast and yeast like strains isolated from tropical environments. J. App. Microbiol. 93: 1020-1025

Chattopadhyay S. and G. Madras. 2003. Kinetics of the enzymatic degradation of poly(Vinyl Acetate) in solution. J. Appl. Polymer Sci. 89: 2579-2582

Covino S., M. Cvancarova, M. Muzikar, K. Svobodova, A. D’annibale, M. Petruccioli, F. Federici, Z. Kresinova and T. Cajthaml. 2010a. An efficient PAH-degrading Lentinus (Panus) Tigrinus strain: Effect of inoculum formulation and pollutant bioavailability in solid matrices. J. Hazard. Mat. 183: 669-676

Covino S., K. Svobodova, A. D'Annibale, M. Cvancarova, M. Petruccioli and F. Federici. 2010b. Effect of inoculum formulation and contaminant bioavailability on PHA degradation performances of Lentinus tigrinus on contaminated solid matrices. J. Biotechnol. 150: S225-S225

Ewis H.E., A.T. Abdelal and C.D. Lu. 2004. Molecular cloning and characterization of two thermostable carboxyl esterases from Geobacillus stearothermophilus. Gene 329: 187-195

Higashimura T., M. Sawamoto, T. Hiza, M. Karaiwa, A. Tsuchii, T. Suzuki. 1983. Effect of methyl substitution on microbial degradation of linear styrene dimers by two soil bacteria. App. Environ. Microbiol. 46: 386-391

Huang H.Z. and J.A. Ottea. 2004. Development of pyrethroid substrates for esterases associated with pyrethroid resistance in the tobacco budworm, Heliothis virescens (F.). J. Agri. Food Chem. 52: 6539-6545

Jang J.H., M. Hirai and M. Shoda. 2006. Enhancement of styrene removal efficiency in biofilter by mixed cultures of Pseudomonas Sp. SR-5. J. Biosci. Bioengin. 102: 53-59

Krishna S.H., M. Persson and U.T. Bornscheuer. 2002. Enantioselective transesterification of a tertiary alcohol by lipase a from Candida antarctica. Tetrahedron Asymmetry 13: 2693-2696

Kudanga T., E. Mwenje, F. Mandivenga and J.S. Read. 2007. Esterases and putative lipases from tropical isolates of Aureobasidium pullulans. J. Basic. Microbiol. 47: 138-147

Lechner B.E. and V.L. Papinutti. 2006. Production of Lignocellulosic enzymes during growth and fruiting of the rdible fungus Lentinus tigrinus on wheat straw. Process Biochem. 41: 594-598
Lowry O.H., H.J. Rosebrough, A.L. Farr and R.J. Randall. 1951. Protein measurement with the folin-phenol reagents. J. Biol. Chem. 193: $265-275$

Maeda H., Y. Yamagata, K. Abe, F. Hasegawa, M. Machida, R. Ishioka, G. Katsuya and N. Tasuku. 2005. Purification and characterization of a biodegradable plastic-degrading enzyme from Aspergillus Oryzae. App. Microbiol. Biotechnol. 67: 778-788

Marcozzi C., I.D.J. Burdett, R.S. Buxton and A.I. Magee. 1998. Expression of both types of desmosomal cadherins and plakoglobin confers strong intercellular adhesion. J. Cell Sci. 111: 495-509

Mester T. and M. Tien. 2004. Oxidation mechanism of ligninolytic enzymes involved in the degradation of environmental pollutants. Inter. J. Biodeterior. Biodegrad. 6: 51-59

Milstein O., R. Gersonde, A. Huttermann, M.J. Chen and J.J. Meister. 1992. Fungal biodegradation of lignopolystyrene graftcopolymers. App. Environ. Microbiol. 58: 3225-3232

Nakamiya K., S. Ooi and T. Kinoshita. 1997. Non-Heme hydroquinone peroxidase from Azotobacter beijerinckii Hm121. J. Ferment. Bioengin. 84: 14-21

Niebisch C.H., M.A. Knoll, S. Ruth, R. Schadeck, D.A. Mitchell, V. Kava-Cordeiro and J. Paba. 2010. Decolorization and biodegradation of reactive blue 220 textile dye by Lentinus crinitus extracellular extract. J. Hazard. Mat. 180: 316-322

Okagbue R.N., E. Mwenje, T. Kudanga, M. Siwela and T. Sibanda. 2001. Isolation of Aureobasidium pullulans from Zimbabwean sources and glucosidase activities of selected isolates. South African J. Bot. 67: 157-160

Ollis D.l., E. Cheah, M. Cygler, B. Dijkstra, F. Frolow, S.M. Franken, M. Harel, S.I. Remington, I. Silman, J. Schrag, J.I. Sussman, K.H.G. Verschueren and A. Goldman. 1992. The alpha/beta-hydrolase fold. Protein Engin. 5: 197-211

Sarnthima R., K. Saranyu and S. Jisnuson. 2009. Extracellular ligninolytic enzymes by Lentinus polychrous LeVol. under solid-state fermentation of potential agro-industrial wastes and their effectiveness in decolorization of synthetic dyes. Biotechnol. Bioprocess Engineer. 14: 513-522

Suzuki Y., K. Miyamoto and H. Ohta. 2004. A novel thermostable esterase from the thermoacidophilic archaeon Sulfolobus tokodaii strain 7. FEMS Microbiol. Lett. 236: 97-102

Takamoto T., P. Kerep, H. Uyama and S. Kobayashi. 2001. Lipasecatalyzed transesterification of polyesters to ester copolymers. Macromol. Biosci. 1: 223-227

Topakas E., C. Vafiadi, P. Christakopoulos. 2007. Microbial production, characterization and applications of feruloyl esterases. Process Biochem. 42: 497-509

Ueda S., Y. Fujio and J.Y. Lim. 1982. Production and some properties of pectic enzymes from Aspergillus oryzae A-3. J. App. Biochem. 4: $524-532$

Webb J.S., M. Nixon, I.M. Eastwood, M. Greenhalgh, G.D. Robson and P.S. Handley. 2006. Fungal colonization and biodeterioration of plasticized polyvinyl chloride. App. Environ. Microbiol. 66 3194-3200

Zheng Y., E.K. Yanful and A.S. Bassi. 2005. A review of plastic waste biodegradation. Crit. Rev. Biotechnol. 25: 43-250 